\title{
Triggering conditions and depositional characteristics of a disastrous debris flow event in Zhouqu city, Gansu Province, northwestern China
}

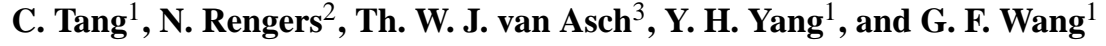 \\ ${ }^{1}$ State Key Laboratory of Geo-Hazard Prevention and Geo-Environment Protection, Chengdu University of Technology, \\ Chengdu, China \\ ${ }^{2}$ Faculty of Geo-Information Science and Earth Observation, Twente University, The Netherlands \\ ${ }^{3}$ Faculty of Geosciences, Utrecht University, The Netherlands
}

Received: 25 June 2011 - Revised: 25 September 2011 - Accepted: 26 September 2011 - Published: 2 November 2011

\begin{abstract}
On 7 August 2010, catastrophic debris flows were triggered by a rainstorm in the catchments of the Sanyanyu and Luojiayu torrents, Zhouqu County, Gansu Province northwestern China. These two debris flows originated shortly after a rainstorm with an intensity of $77.3 \mathrm{~mm} \mathrm{~h}^{-1}$ and transported a total volume of about 2.2 million $\mathrm{m}^{3}$, which was deposited on an existing debris fan and into a river. This catastrophic event killed 1765 people living on this densely urbanised fan. The poorly sorted sediment contains boulders up to 3-4 $\mathrm{m}$ in diameter. In this study, the geomorphological features of both debris flow catchment areas are analyzed based on the interpretation of high-resolution remote sensing imagery combined with field investigation. The characteristics of the triggering rainfall and the initiation of the debris flow occurrence are discussed. Using empirical equations, the peak velocities and discharges of the debris flows were estimated to be around $9.7 \mathrm{~m} \mathrm{~s}^{-1}$ and $1358 \mathrm{~m}^{3} \mathrm{~s}^{-1}$ for the Sanyanyu torrent and $11 \mathrm{~m} \mathrm{~s}^{-1}$ and $572 \mathrm{~m}^{3} \mathrm{~s}^{-1}$ for the Luojiayu torrent. The results of this study contribute to a better understanding of the conditions leading to catastrophic debris flow events.
\end{abstract}

\section{Introduction}

Rapid gravitational debris flows, which may deposit significant volumes of material on inhabited alluvial fans, pose severe hazards in mountain areas (Varnes, 1978; Jakob and Hungr, 2005). This is due to their high velocities, large volumes, and frequent occurrence in a wide spectrum of morphological settings (Hürlimann et al., 2006). Three factors are essential for the development of debris flows: sufficient available loose material, considerable steepness of the drainage channels on the catchment slopes and the generation of an ample amount of surface run-off (Takahashi, 1981).

Two giant debris-flows developed in the Sanyanyu and Luojiayu catchments, Zhouqu County, Gansu Province, northwestern China, on 7 August 2010. They killed 1765 people living on the existing alluvial fan. These catastrophic debris flows were triggered by an intense local rainstorm and led to the destruction of more than 5500 houses along their flow paths. In addition, the debris flows transported huge amounts of sediment into the Bailong River to form a temporary debris-dam, which resulted in flooding of a large urbanized area. The debris flows showed unusually high flow discharges and huge volumes of transported debris, compared to many other events that occurred in this region (LIGC and TSIG, 1982).

To document this catastrophic event and to explore the characteristics of the debris flows initiation, a field investigation combined with interpretation of high-resolution remote sensing imagery prior to and after the event was conducted in this disaster-hit area. The aim of this paper is to describe the characteristics of the event: the debris-flow source areas, the transport paths and the deposits and to estimate the debrisflow volumes, the peak velocities, and discharges. Based on these observations, suggestions are given to improve future hazard assessments and the design of protective measures.

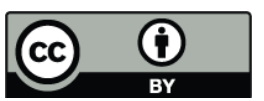

Correspondence to: C. Tang

(tangc707@gmail.com)

Published by Copernicus Publications on behalf of the European Geosciences Union. 


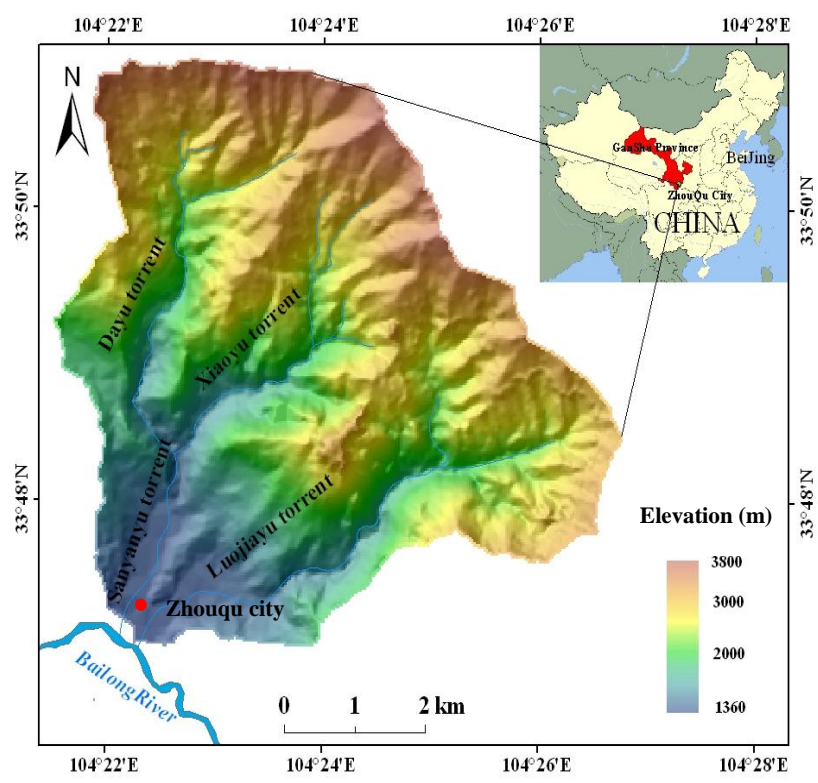

Fig. 1. The debris flow locations near Zhouqu City.

\section{Study area}

The study area belongs to the transitional mountainous region between the southeastern edge of the Tibetan Plateau and the Qinling and Longmen mountain ranges. It is characterized by rugged mountains with elevations between $1000 \mathrm{~m}$ and $4000 \mathrm{~m}$ a.s.l. and deeply incised valleys (Hu et al., 2010). The area is located at the westernmost extension of the tectonic belt of west Qinling, which was greatly affected by the Indosinian, Yanshan, and the Himalayan orogenic deformations. As a result, the Zhouqu area belongs to an active earthquake region. A historical destructive earthquake occurred in the Wenxian and Zhouqu regions on 1 July 1879 with a magnitude of $M_{\mathrm{S}}=8.0$. With this magnitude, the Zhouqu area was located in a very high seismic intensity zone with a Chinese seismic intensity IX. According to Ma and Qi (1997), this earthquake event strongly contributed to the landslide activity in the Sanyanyu and Loujiayu catchments. It should be noted that the Zhouqu area also belongs to the area which was affected by the 12 May $2008 M_{\mathrm{s}}=8.0$ Wenchuan earthquake. The Zhouqu area was located in an area with a Chinese seismic intensity VI. However, no significant landslides were triggered by this earthquake.

The geology of the study area is mainly composed of Silurian slates and phillites, Permian limestones, and Devonian limestones and slates. Quaternary deposits are present in the form of river terraces and alluvial fans. The bedrock is deeply fractured and highly weathered. Rocks exposed in the source areas are highly weathered limestones of the Daguan complex.

The Sanyanyu and Luojiayu torrents are located near the city of Zhouqu and are tributaries of the Bailong River.
Table 1. Main morphometric parameters of Sanyanyu and Luojiayu basin and channel.

\begin{tabular}{lrr}
\hline & $\begin{array}{r}\text { Sanyanyu } \\
\text { torrent }\end{array}$ & $\begin{array}{r}\text { Luojiayu } \\
\text { torrent }\end{array}$ \\
\hline Basin area $\left(\mathrm{km}^{2}\right)$ & 25.75 & 16.14 \\
Basin maximum elevation (m a.s.l.) & 3830 & 3780 \\
Basin outlet elevation (m a.s.l.) & 1340 & 1330 \\
Average basin slope $\left({ }^{\circ}\right)$ & 14.3 & 14.1 \\
Channel length $(\mathrm{m})$ & 10.4 & 9.5 \\
Channel slope in the initiation area $\left({ }^{\circ}\right)$ & 39 & 36 \\
Channel slope in the deposition area $\left(^{\circ}\right)$ & 5.7 & 7.8 \\
Average channel gradient $\left({ }^{\circ}\right)$ & 13.4 & 12.5 \\
\hline
\end{tabular}

Zhouqu city is situated about $280 \mathrm{~km}$ northwest of Lanzhou City and $400 \mathrm{~km}$ north of Chengdu City (Fig. 1). The main branch of the Sanyanyu catchment has a length of $10.4 \mathrm{~km}$ and a drainage area of $25.7 \mathrm{~km}^{2}$. In the middle part of the channel at an elevation of $1580 \mathrm{~m}$ a.s.l., it splits into two branches, of which the western one is named the Dayu torrent, and the eastern one is called the Xiaoyu torrent (Fig. 1). The Luojiayu torrent has a length of $9.5 \mathrm{~km}$ and a drainage area of $16.14 \mathrm{~km}^{2}$. In the debris flow initiation area, the gradient of the channels varies between $36^{\circ}$ and $39^{\circ}$, while the average channel gradient of the catchments varies around $13^{\circ}$ (Table 1).

The study area has a semi-arid to arid climate characterized by scanty rainfall with an annual average precipitation of $434 \mathrm{~mm}$. The maximum recorded daily and hourly rainfall intensity was $62.9 \mathrm{~mm}$ and $40.7 \mathrm{~mm}$ in 1994, respectively. The rainfall is largely concentrated in the period from June to September. On average, $75 \%$ of the annual precipitation falls during this period.

\section{Rainfall trigger for the 7 August debris flows}

A rain-gage was located in the Dongshan area at about $10 \mathrm{~km}$ northeast of Zhouqu city. Yu et al. (2010) and Zhao et al. (2010) assumed that this rain-gage most likely has recorded the amount of rain which triggered the debris-flows because of its location at a high elevation ( $2150 \mathrm{~m}$ a.s.1.). The recorded data show that precipitation in the Zhouqu area started at 8:00 p.m. on 7 August. The accumulated rainfall of $96.7 \mathrm{~mm}$ was recorded from 8:00 p.m. on 7 August to 04:00 a.m. on 8 August (Fig. 2). This is an amount with a return period of more than $100 \mathrm{yr}$ (Zhao et al., 2010). The rainfall intensity that triggered the debris flows occurred between 11:00 and 12:00 p.m.: $77.3 \mathrm{~mm} \mathrm{~h}^{-1}$ was recorded during that hour. Many eyewitnesses in Zhouqu city stated that the debris flows started around 11:40 p.m. and ended at 00:30 a.m. next day. After the end of the debris flows, high water discharges were reported in the stream channels until 10:00 a.m. on 8 August. 


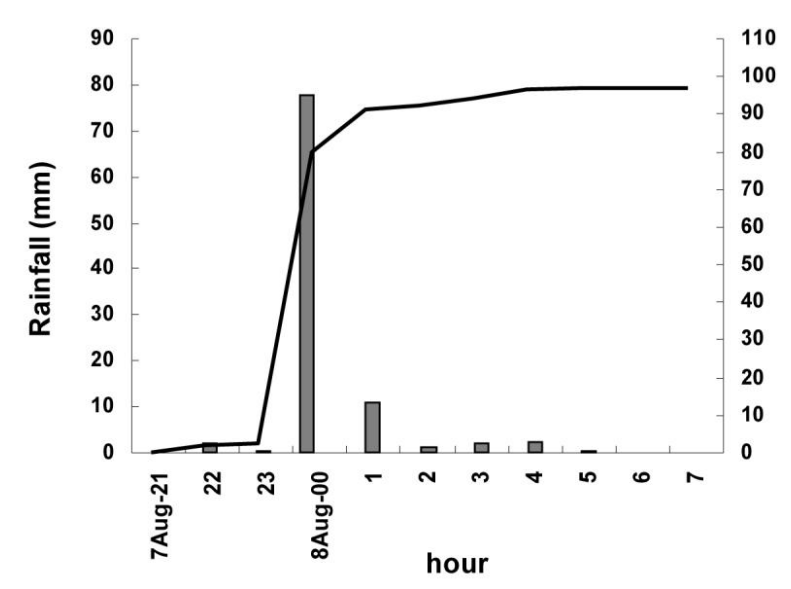

Fig. 2. Hourly and cumulative rainfall on 7 and 8 August 2010 at Dongshan rain-gage station.

It should be noted that the summer of 2010 was marked by a very low amount of rainfall in the Zhouqu area prior to 7 August. According to rainfall records from 1970 to 2007 at the Dongshan station, the average amount of monthly rainfall for August is $74.7 \mathrm{~mm}$ (Qu et al., 2010). Thus, the accumulated rainfall of $96.7 \mathrm{~mm}$ and the hourly rainfall intensity of $77.3 \mathrm{~mm}$ for the event on 7-8 August 2010 exceeded the mean monthly rainfall value for August in the debris flow source area.

Debris flows usually occur as a consequence of a combination of high accumulated (antecedent) rainfall and very high rainfall intensity (Costa, 1984). In this event, however, the peak rainfall intensity (7 August, 11:00-12:00 p.m.: $77.3 \mathrm{~mm} \mathrm{~h}^{-1}$ ) was the significant triggering factor as the accumulated antecedent rainfall over $24 \mathrm{~h}$ was only $6.5 \mathrm{~mm}$, which did not obviously contribute to the triggering of this event. Qu et al. (2010) and Zhao et al. (2010) noted that in the Zhouqu area, rainstorms are characterized by short duration (normally $1 \mathrm{~h}$ ) and high intensities. The triggering threshold in this region seems to be mainly related to high-intensity precipitation.

Historical documents show that only high intensity rainfall events are able to initiate debris flows along the Bailong River in the Zhouqu area. According to data from Ma and Qi (1997), the rainfall events which triggered debris flows ranged in intensity between 37 and $47 \mathrm{~mm} \mathrm{~h}^{-1}$ in the Sanyanyu catchment (Table 2). It was also found that debris flows near Zhouqu city occur when 10-min rainfall reaches $5-8 \mathrm{~mm}$ or 30-min rainfall totals more than $10 \mathrm{~mm}$ (Ma and Qi, 1997). Compared with these historical events, the debris flows on August 7 were really catastrophic because they transported about 1.4 million $\mathrm{m}^{3}$ sediment to the Bailong River, while the historical debris flows usually had volumes of $0.20-0.55$ million $\mathrm{m}^{3}$.

www.nat-hazards-earth-syst-sci.net/11/2903/2011/

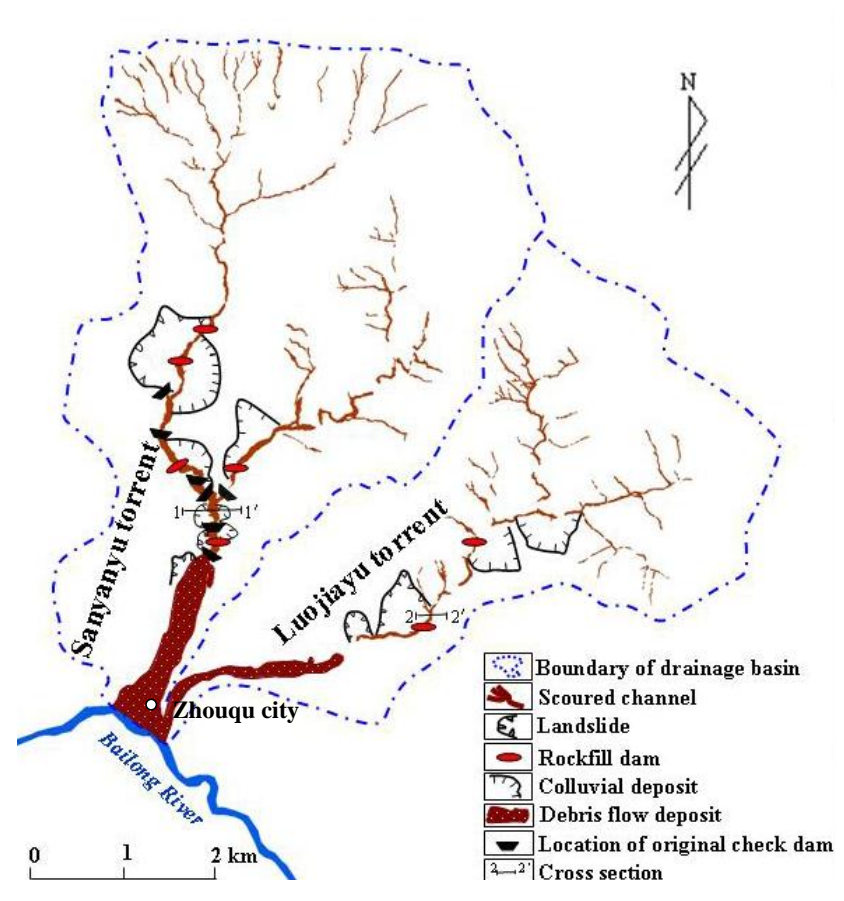

Fig. 3. Geomorphological sketch map of the Sanyangyu and Luojiayu catchments based on field investigations combined with the interpretation of a Quickbird image taken on 15 August 2010 (immediately after the Zhouqu debris flows occurrence).

Table 2. Characteristics of historical rainstorms producing debris flows in the Sanyanyu torrent.

\begin{tabular}{lll}
\hline Date & $\begin{array}{l}\text { Rainfall } \\
\text { amount }(\mathrm{mm})\end{array}$ & Duration \\
\hline $15-07-1978$ & 37.4 & $1 \mathrm{~h}$ \\
$18-06-1982$ & 46.8 & $1 \mathrm{~h}$ \\
$10-05-1989$ & 47.0 & $1 \mathrm{~h}$ \\
$04-06-1992$ & 38.4 & $45 \mathrm{~min}$ \\
$07-08-1994$ & 63.3 & $2 \mathrm{~h}$ \\
\hline
\end{tabular}

\section{Development of debris flows in the initiation zone and transport zone}

Recent imagery can be compared with imagery before the 7 August debris flow event to examine the development of the debris flows. In this study, remote sensing and GIS technology, along with field reconnaissance, were used to conduct geomorphological mapping and to characterize the debris flows. Quickbird imagery $(0.61 \mathrm{~m}$ resolution) taken on 15 August 2010 (just after the event) and Worldview imagery $(0.5 \mathrm{~m}$ resolution) taken on 16 May 2010 (prior to the event) were compared to analyze differences between the geomorphological features in the debris flow catchments (Fig. 3). This way the scoured channel and slope failures could be easily identified and mapped. The comparison 


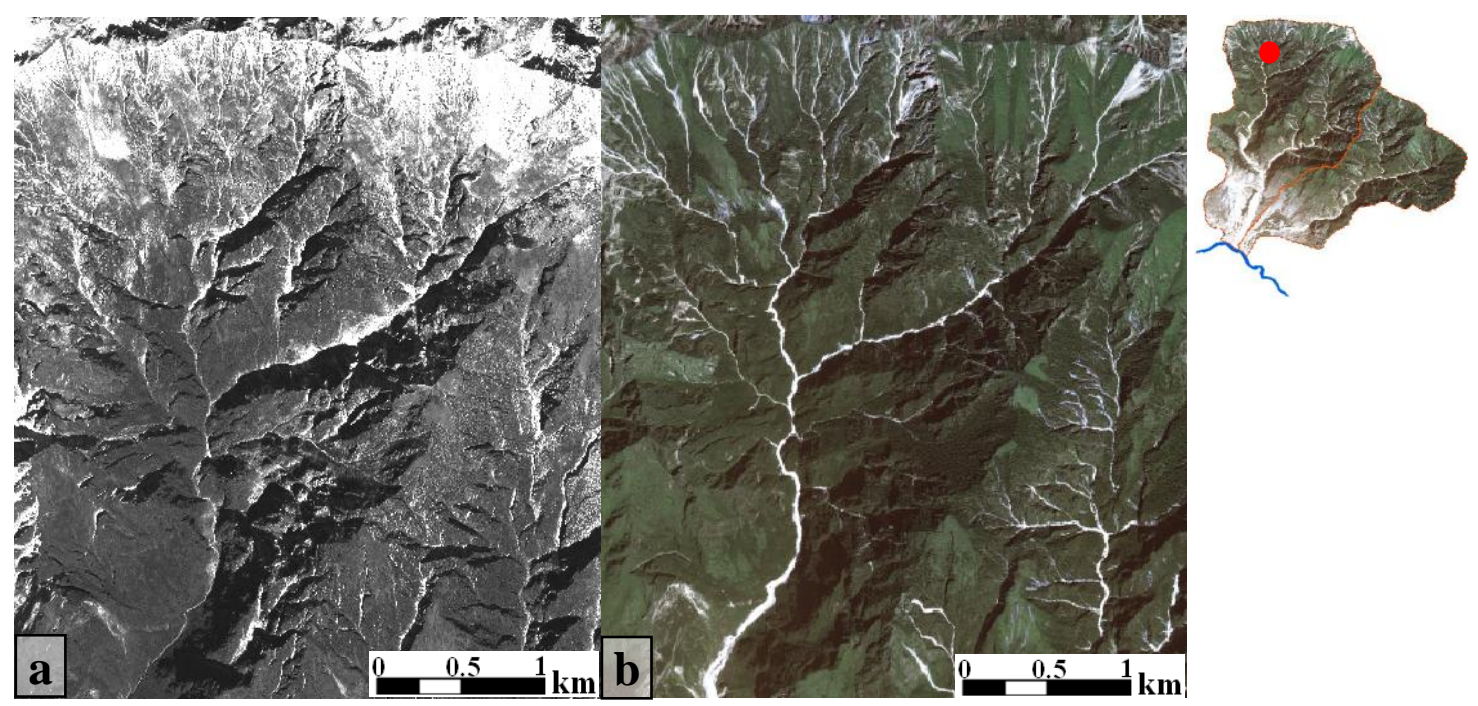

Fig. 4. Imagery showing the debris flow development in the initiation area of the Sanyangyu basin by comparison of imagery prior to and after the rainstorm event (a: Worldview image taken on 16 May 2010 prior to the event; b: Quickbird image taken on 15 August 2010 after the event).

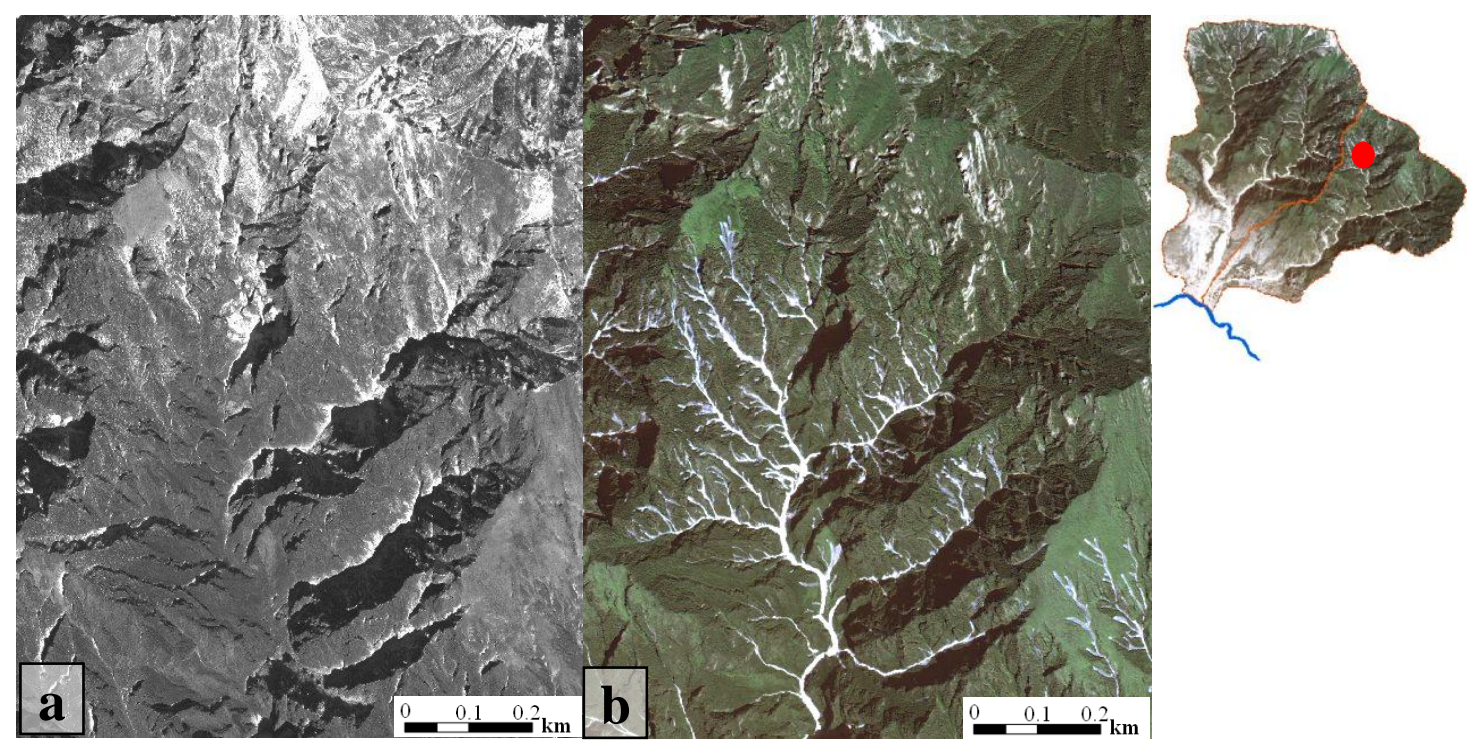

Fig. 5. Imagery showing the debris flow initiation sites of the Luojiayu basin by comparison of imagery prior to and after the rainstorm event (a: Worldview image taken on 16 May 2010 prior to the event; b: Quickbird image taken on 15 August 2010 after the event). The scoured gullies were considerably widened due to upstream overland flow after the event.

showed significant changes in the channels in the debris flow initiation area at an elevation over $2400 \mathrm{~m}$ a.s.l. Initiation sites were marked by fresh scouring within or near an ephemeral channel. Figures 4 and 5 show evidence of scouring of the original channels in the initiation area of the Sanyanyu and Luojiayu torrents: the torrent banks were greatly widened after the rainstorm event. According to the "Report of the Survey of the Sanyangyu debris flow hazards in Zhouqu County, Gansu Province" compiled by the Northwestern Branch of the Survey and Design Bureau for Geological Hazards in 2010, the incision depth is $0.5-1.5 \mathrm{~m}$ and the debris flow tracks widened from the original $2-4 \mathrm{~m}$ to the present 5-9 $\mathrm{m}$ in the upstream rills of the initiation area of the Sanyangyu catchment. These features demonstrate that the initiation of debris flows in these two catchments started with significant upstream channel erosion and transport of highly 


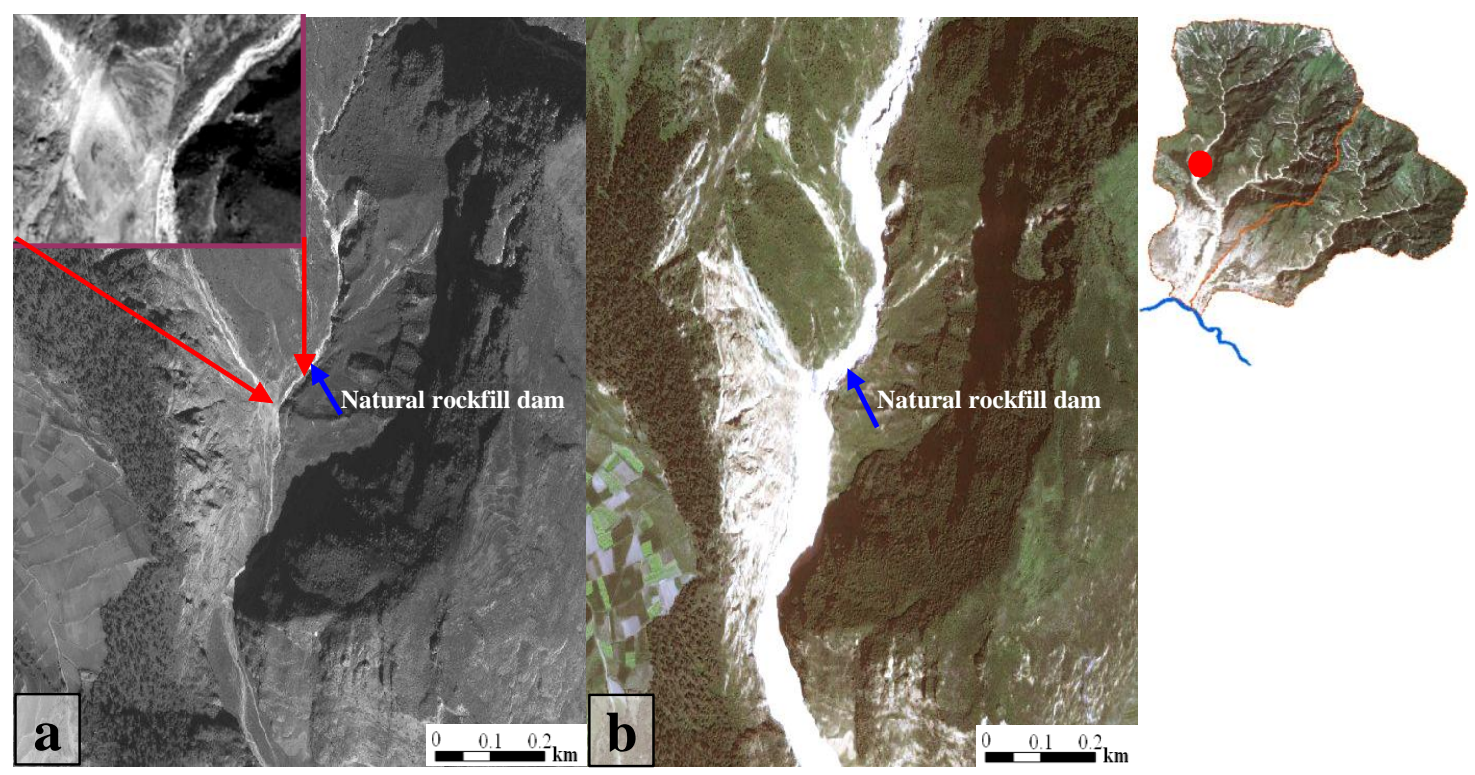

Fig. 6. Imagery showing erosive features of the debris flow channel and hillslope failures in colluvial deposits in the transport zone of the Sanyangyu catchment after the rainstorm event. The breaching of a significant natural rockfill dam resulted in intensive channel erosion and an instant increase in the flow discharge.

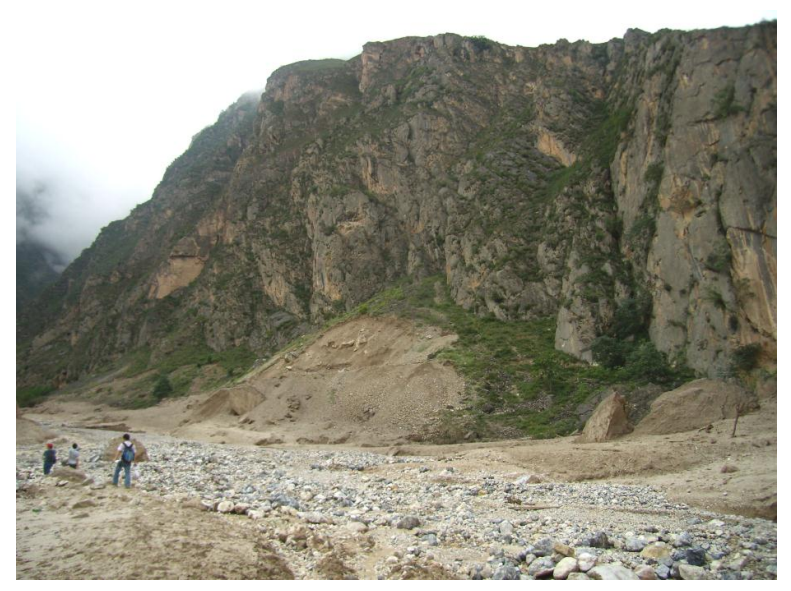

Fig. 7. Colluvial deposit derived from rockfall. The erosion by the massive and rapid debris flow resulted in colluvium failure producing more sediment volume for the debris flow.

weathered sediment after the surface runoff was concentrated in these very steep channels. The mobilized channel-bed material continually scoured and entrained additional debris and progressively increased the solid concentration of the flow transforming it into a debris flow.

Many colluvial deposits derived from rockfall and other mass-wasting processes were observed in the transport zone of the Sanyanyu torrent, which may have contributed to debris flow occurrence (Figs. 6 and 7). Geomorphological mapping (Fig. 3) indicates that colluvial deposits were mainly present along and near torrents exposed by erosion triggered by channel incision.

In the two catchments, we also found some large landslides triggered by the 1879 Wenxian earthquake near Zhouqu city during our field investigation. However, there are no evidences of remobilization of these landslides or that they were involved in debris flow generation. Shallow landslides in the middle reach of the catchments were found to remove $3-8 \mathrm{~m}$ of colluvium from the hillslopes to fill up the channels. At least five natural rockfill dams that were produced by the 1879 strong earthquake or rockfalls were identified during field investigations along the Sanyanyu torrent (Figs. 3 and 8). These rockfill dams usually have a height of $40-120 \mathrm{~m}$ at an altitude level between $1560 \mathrm{~m}$ and $1700 \mathrm{~m}$ a.s.l. (Fig. 9). Field observations showed that the incipient debris-flows triggered upstreams causing the failure of these rockfill dams. One significant failure of a rockfill dam occurred in the lower reach of Dayu gully (Fig. 6), and then the debris flow intensively eroded the soil and regolith on the right hillslope and entrained a large amount of material to the flow, resulting in an instant increase in the flow discharge and also a longer runout distance. Yu et al. (2010) estimated that the peak discharge of the debris flow increased at least $60 \%$ due to the breaching of the rockfill dams in the Sanyangyu torrent.

Seven check dams had been constructed as stone masonry structures since 1997. In Fig. 3, the locations of these original check dams are shown. These check dams have average dimensions of 20-40 long and 4-8 $\mathrm{m}$ high and the basin behind them had been filled half or totally before the event. 


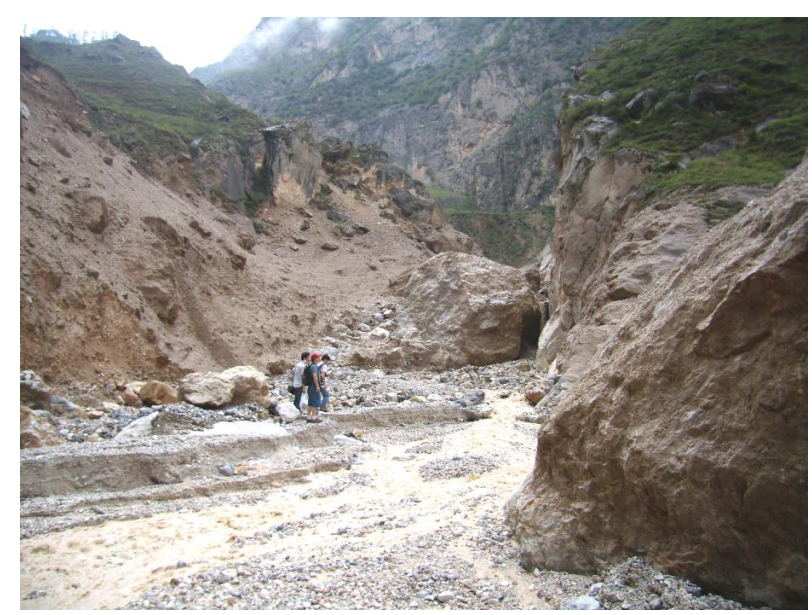

Fig. 8. Natural rockfill dam in the Sanyangyu torrent, which was scoured by the 7 August 2010 debris flow event. Only a large boulder was left in the channel after breaching of the dam.

However, all of them were destroyed during this catastrophic event (Figs. 10 and 11). Field reconnaissance indicated that the debris flow also incorporated $10-15 \%$ of all materials stored behind the check dams into the flow due to the dam failure. However, the failure of the check dams did not result in a significant increase of flow volume and erosive potential as compared with the natural rockfill dam breach.

No local residents observed the debris flow process in the dark because of the power cutoff around Zhouqu city immediately after the debris flow event occurred. Field evidences indicated that the debris flow in the Sanyangyu torrent developed in several pulses. However, the first pulse was the largest one that reached a height of about $5.0 \mathrm{~m}$ in sections $1-1^{\prime}$. This surge rapidly filled the channel and spread over the existing alluvial fan into the urban area. The height of the follow-up surges was estimated to be 1-2 m. It stopped at the upper part of the downstream torrent. For the Luojiayu torrent, field evidence indicated that the fan experienced only one pulse of debris flow. In section $2-2^{\prime}$, fresh mud on the banks recorded a maximum flow depth of about $2.7 \mathrm{~m}$.

To further understand the dimension of incision by erosion during the debris flow in different reaches of the torrent, some typical cross sections were measured by suspending a horizontal string across the channel and measuring its height over the terrain surface at various points of the cross-section. These field measurements indicate that at elevations between $1500 \mathrm{~m}$ and 1650 a.s.l. the channels widened from the original $20-40 \mathrm{~m}$ to the present $60-90 \mathrm{~m}$, over a length of more than $2.5 \mathrm{~km}$ for the Sanyanyu main torrent (Dayu torrent) and $2.9 \mathrm{~km}$ for the Luojiayu torrent. The incision depth ranged from $4 \mathrm{~m}$ in the upper part to $2 \mathrm{~m}$ in the lower part. Figure 9 also shows that in the main channel of the Sanyanyu catchment, additional debris was progressively incorporated through bed and bank erosion. These evidences indicated

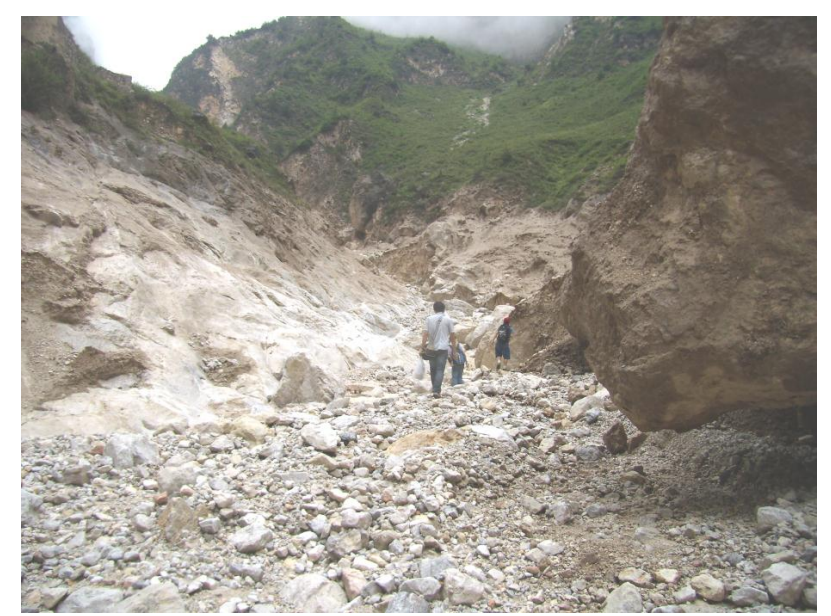

Fig. 9. Main flow track of the Sanyangyu torrent. The channel banks were scoured and widened after debris flow moved downslope.

that erosion and entrainment of material were significant in the upper and middle parts of the torrent as demonstrated by the fines enrichment and volume increase of the flowing mass along the channel itself.

As the debris flows traveled though the torrent channels of the downstream reaches, the discharges increased and additional material was incorporated from colluvial deposits and sediments from collapse of rockfill dams. Large- sized material stored within the channel bed in the transport zone was also incorporated into the flows and was subsequently transported out onto the debris fans as boulder-sized material in an abundant fine-grained matrix. A field estimation indicated that the Sanyanyu debris flow transported more than 1.2 million $\mathrm{m}^{3}$ material from the source catchment to the Bailong River.

\section{Depositional characteristics of the debris flows}

Zhouqu city was located on a severly damaged alluvial fan during the August 2010 event. Figures 11 and 12 show that the main damage due to the debris flows occurred in the central part of their depositional fan. At the fan apex, the peak volume of flow, probably during a debris-flow surge, exceeded the channel capacity resulting in the debris flows spreading boulders over the whole fan. The flows inundated the second storey of many apartment buildings, causing their partial collapse (Fig. 13), and also buried or completely destroyed many one and two-storey residential structures (Fig. 14).

Using field measurement, we determined that the depositional fan of the Sanyanyu debris flow has a length of more than $2.1 \mathrm{~km}$ and an average width of $190 \mathrm{~m}$ (Figs. 3 and 11), while the Luojiayu debris flow fan is more than $2.2 \mathrm{~km}$ long 

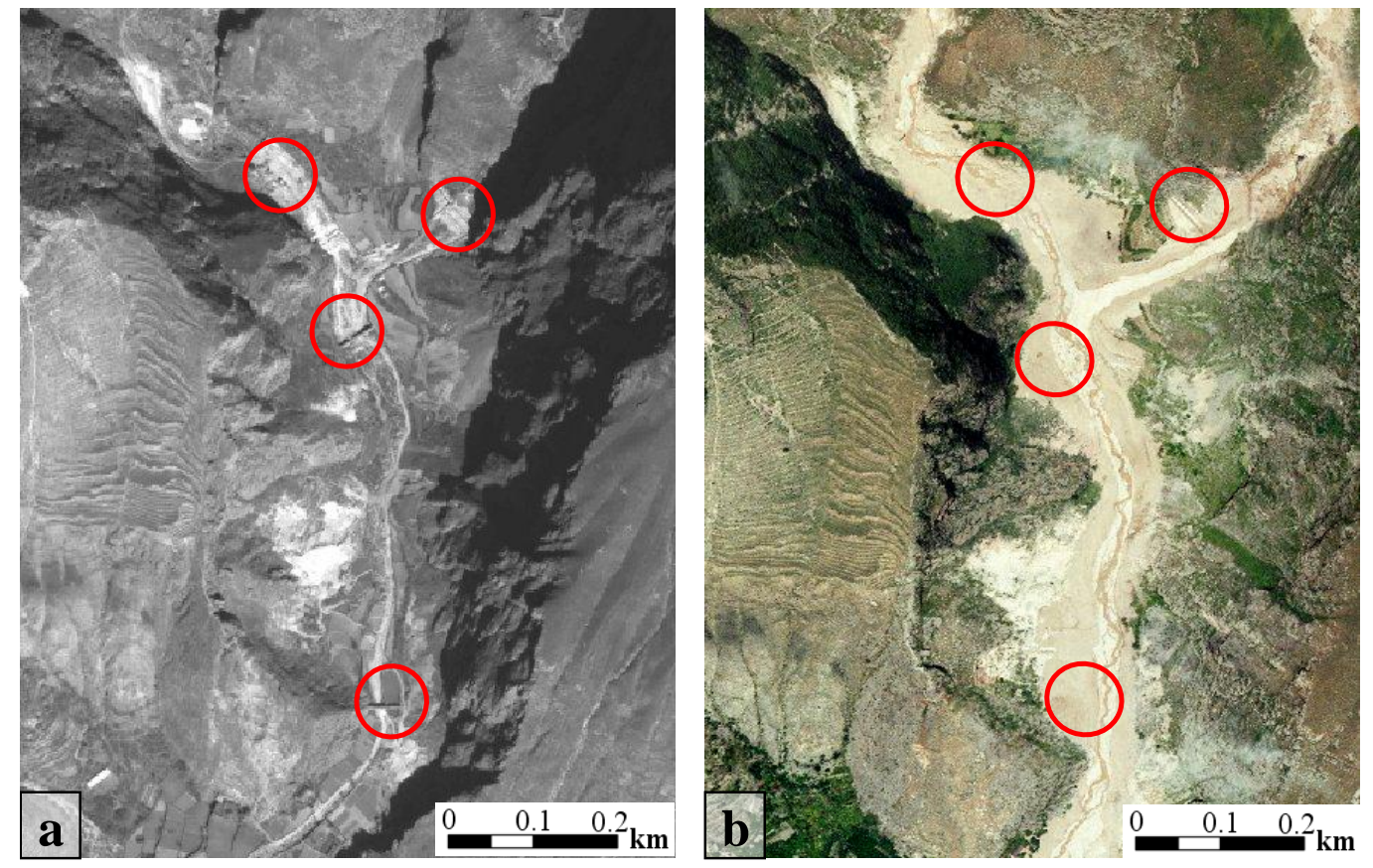

Fig. 10. Comparison of the imageries prior to and after the event showing that four previous debris flow control structures were destroyed in the Sanyangyu torrent. (a: Worldview image taken on 16 May 2010 prior to the event; b: Quickbird image taken on 15 August 2010 after the Zhouqu debris flow event.)

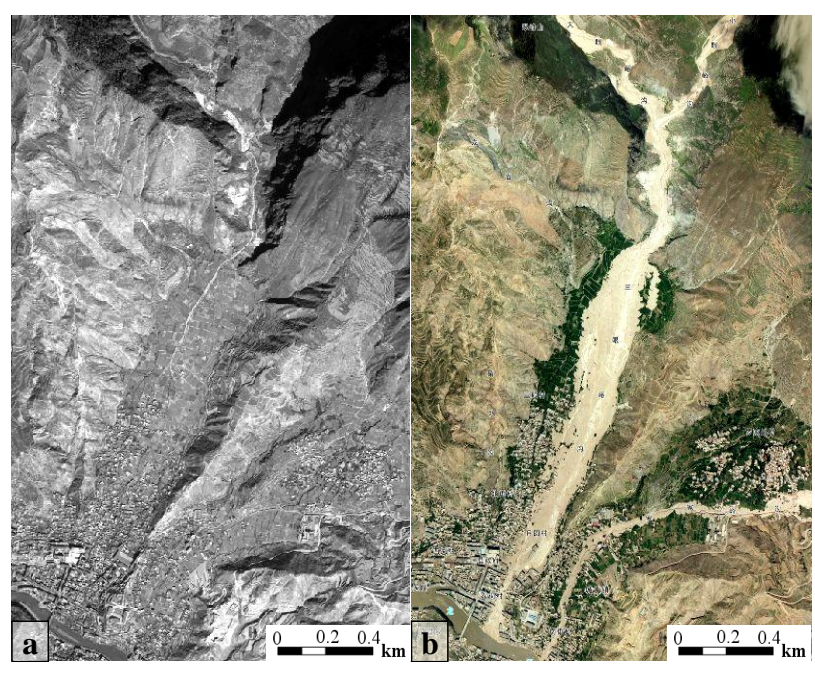

Fig. 11. Alluvial fan prior to and after the debris flow event. (a: Worldview image taken on 16 May 2010 prior to the event, showing the densely urbanized area in Zhouqu city; b: Quickbird image taken on 15 August 2010 after the Zhouqu debris flow event, showing the depositional zone of the debris flows. New debris flow deposits can be easily distinguished by their lighter tone.)

with an average width of $70 \mathrm{~m}$. The average thickness of the two debris flow deposits was estimated to be $2-6 \mathrm{~m}$ on top of the existing alluvial fans. Both alluvial fans were totally inundated by flows in this event. The deposited material, still in a liquid state one day after motion stopped, did not show water losses at the front or in any other parts. Subsequent stream flow partially eroded the channel bed and the terminal deposits, transporting finer sediment beyond the coarse debris lobe.

The depositional fans extended into the Bailong River and produced a temporary debris-dam. It is difficult to determine the thickness of subaqueous deposits, but they were probably more than $9 \mathrm{~m}$ thick. This debris-dam raised the water level more than $8 \mathrm{~m}$ causing severe flooding in the Zhouqu city (Fig. 15). This debris dam was estimated to be $10 \mathrm{~m}$ in height, $70 \mathrm{~m}$ in length across the river, and $450 \mathrm{~m}$ in length along the river, resulting at the upstream side in a dammed lake with a length of $3 \mathrm{~km}$. One third of Zhouqu city was inundated for 5 days. In order to reduce the urban flooding risk, emergency response was undertaken to remove the boulders and the finer-grained particles in a channel through the crest of the debris dam (Fig. 16). After five days, an artificial spillway was completed to successfully release the impounded water.

Debris-flow deposits typically are massively textured, poorly sorted, matrix- supported mixtures of sediment ranging in size from clay to cobbles and boulders of several meters in diameter (Pierson, 1980; Suwa and Okuda, 1983; Costa, 1984; Tang et al., 2009). Results from grain size analysis indicate that fine-grained materials are much more 


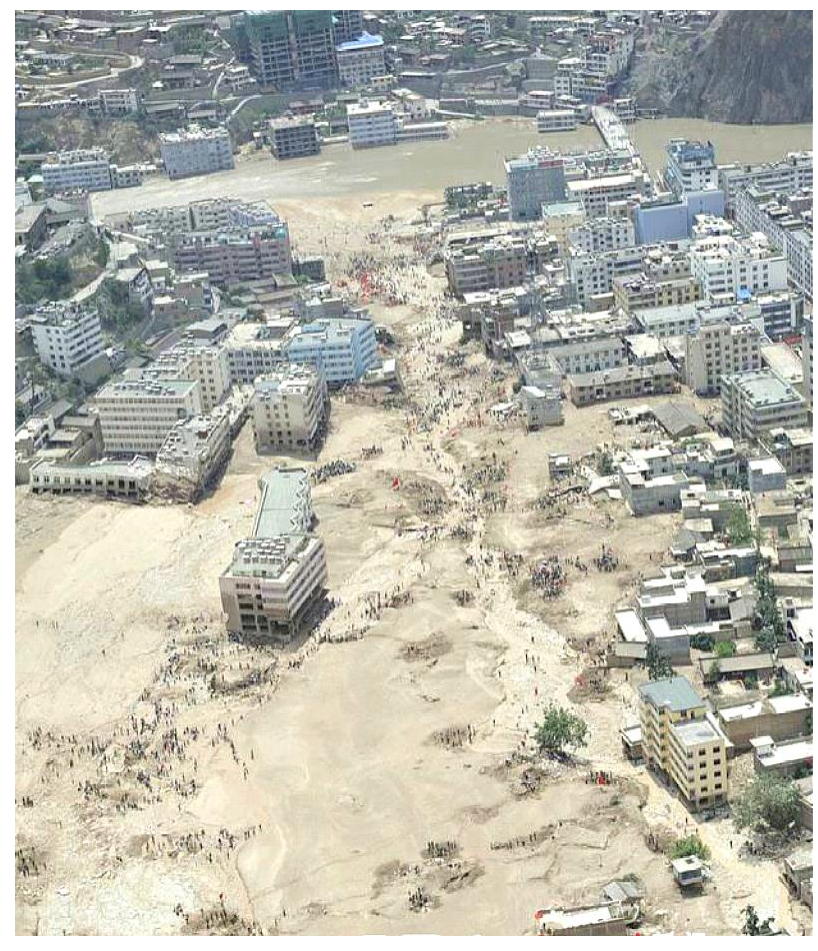

Fig. 12. The devastating amount of sediment and debris transported onto the existing alluvial fan as a result of the major debris flow of Zhouqu, China, 2010.

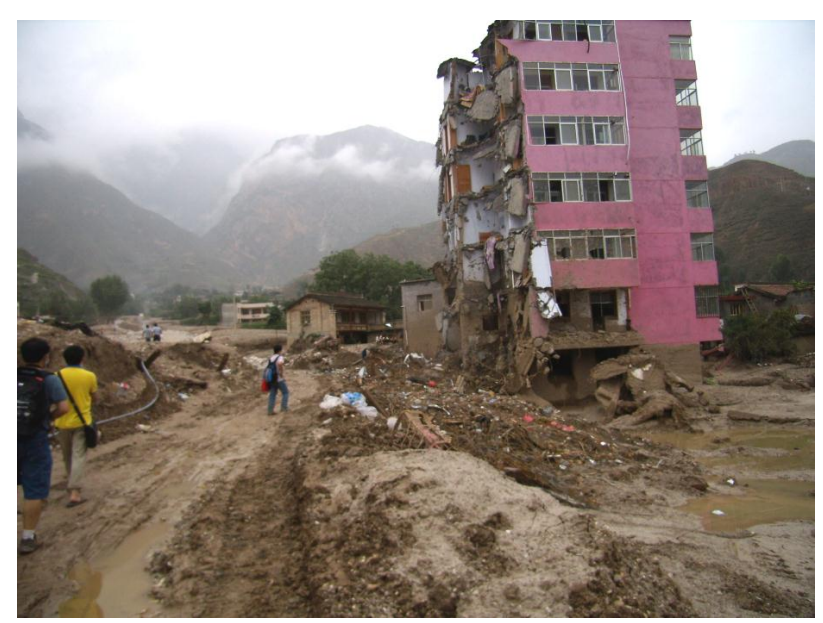

Fig. 13. Apartment buildings in Zhouqu city extensively damaged by the passage of the debris flow front of at least $4 \mathrm{~m}$ in height.

abundant than coarse-grained materials in the matrix of the depositional fans of the debris flows in the study area (Yu et al., 2010). Field observation showed that most of the coarsegrained particles were accumulated in the highest part of the fan. The largest boulders deposited on the fan exceed a diameter of $6 \mathrm{~m}$ (Fig. 16).

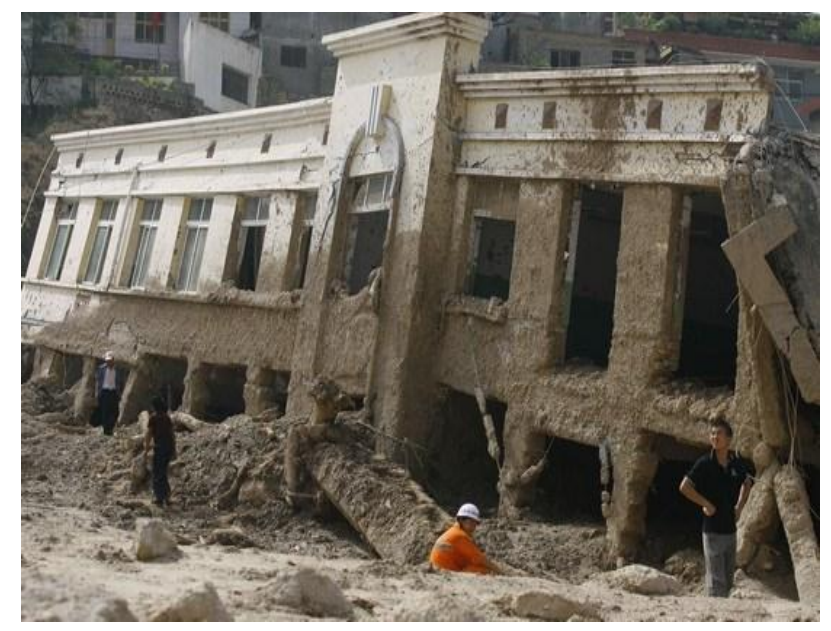

Fig. 14. A two-storey building was totally destroyed due to the direct impact of debris flow. Mud trance still remained on the wall of the building.

\section{Debris-flow volume, velocity, and discharge}

For hazard assessment on a fan and the design of protective measures, it is necessary to estimate the most important impact parameters such as flow volume, flow velocity, and peak discharge (Rickenmann, 1999). The data collected on the thickness and the extent of the fan deposits were used to estimate the total volume of the deposits on the fan. A quick field measurement with hand-held GPS and laser Rangefinders showed a total volume of 1.4 million $\mathrm{m}^{3}$ for the Sanyanyu debris flow and 0.8 million $\mathrm{m}^{3}$ for the Luojiayu debris flow. These volumes are minimum values because the amount of the finer debris-flow matrix from the upper part of the boulder deposit that was removed by post-debris flow flooding and the amount of deposited material that remained in the main channel after the event were neglected.

Debris flow velocities are conventionally back-calculated from super-elevation of the flow in channel bends (Johnson, 1984; Prochaska et al., 2008). The regression equations obtained from combinations of flow depth and channel slope are also widely used to determine debris flow velocity (Hungr et al., 1984; Rickenmann, 1999; Prochaska et al., 2008). In this study, the maximum (mean cross-sectional) velocity and discharge were estimated from the data obtained by site surveying of several typical transverse channel sections, where the mud traces of the debris flow on the gully banks were still visible. The peak velocity $V_{c}$ and peak discharge $Q_{c}$ were then estimated by empirical relations given by Eqs. (1) and (2), which combine flow depth and channel slope. 


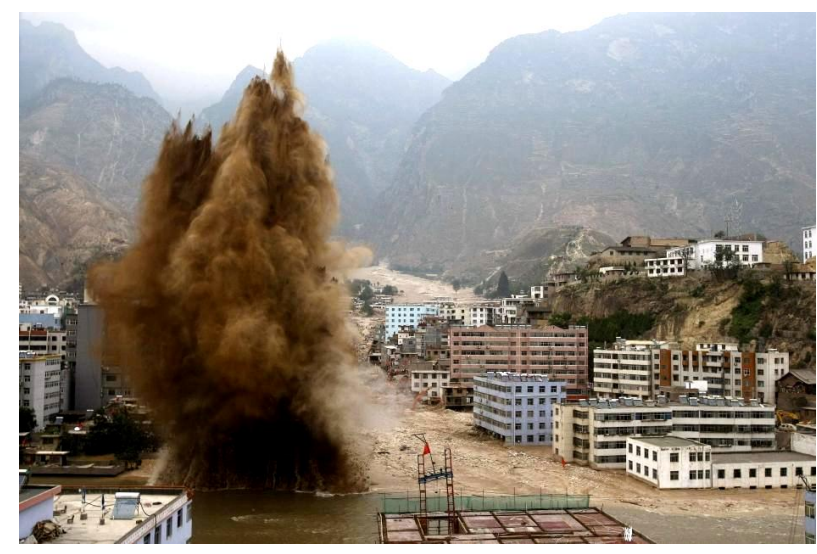

Fig. 15. Breaching of the debris-dams that partially blocked the river, raising the riverbed. After five days, an artificial spillway was completed to successfully release the impounded water.

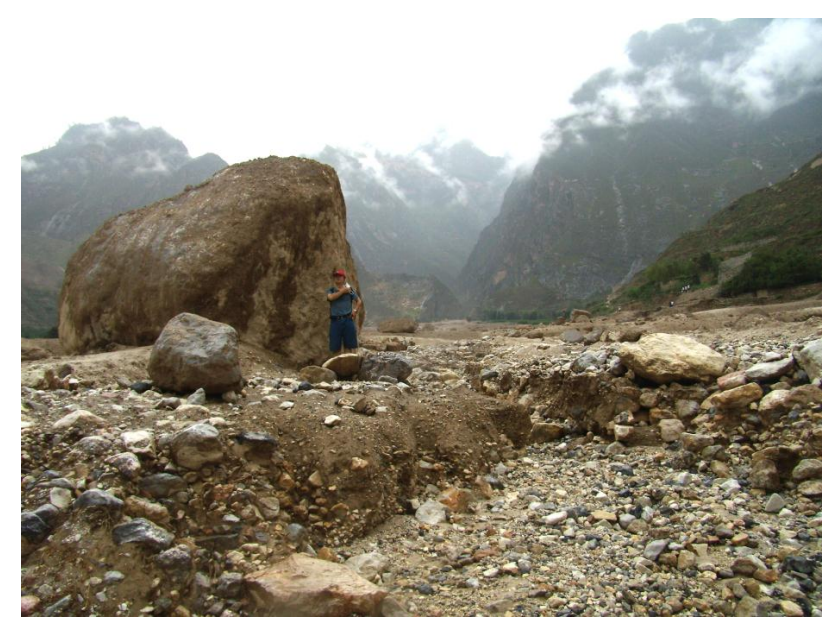

Fig. 16. Photography showing the largest boulder (which exceeded a diameter of $6 \mathrm{~m}$ ) deposited in the depositional zone when the flow spread out over agricultural terraces.

$$
\begin{aligned}
& V_{c}=K_{c} H_{c}^{2 / 3} I^{1 / 5} \\
& Q_{c}=W_{c} V_{c}
\end{aligned}
$$

where

$V_{c}$ is the peak velocity of the debris flow $\left(\mathrm{m} \mathrm{s}^{-1}\right)$;

$K_{c}$ is a factor that is related to debris flow depth according to Table 3;

$H_{c}$ is the debris-flow depth determined by measurement of mud trace at the cross sections $(\mathrm{m})$;

$I$ is the longitudinal slope gradient of channel bed (\%o);

$Q_{c}$ is the peak discharge of debris flow $\left(\mathrm{m}^{3} \mathrm{~s}^{-1}\right)$;

$W_{c}$ is the cross-sectional area $\left(\mathrm{m}^{2}\right)$.

The formulae used for velocity estimation have the same form as the Chézy model, Rickenmann and Hungr model
Table 3. Relationship between the velocity coefficient $\left(K_{c}\right)$ and debris flow depth $\left(H_{c}\right)$.

\begin{tabular}{lcccccccc}
\hline$H_{c}(\mathrm{~m})$ & $<2.5$ & 2.75 & 3 & 3.5 & 4 & 4.5 & 5 & $>5.5$ \\
\hline$K_{c}$ & 10.0 & 9.5 & 9.0 & 8.0 & 7.0 & 6.0 & 5.0 & 4.0 \\
\hline
\end{tabular}

Table 4. The calculation results of debris-flow parameters in sections $1-1^{\prime}$ and $2-2^{\prime}$ (Fig. 3).

\begin{tabular}{lcccccc}
\hline $\begin{array}{l}\text { Cross- } \\
\text { section }\end{array}$ & $K_{c}$ & $\begin{array}{c}I \\
(\% o)\end{array}$ & $\begin{array}{c}H_{c} \\
(\mathrm{~m})\end{array}$ & $\begin{array}{c}V_{c} \\
\left(\mathrm{~m} \mathrm{~s}^{-1}\right)\end{array}$ & $\begin{array}{c}W_{c} \\
\left(\mathrm{~m}^{2}\right)\end{array}$ & $\begin{array}{c}Q_{c} \\
\left(\mathrm{~m}^{3} \mathrm{~s}^{-1}\right)\end{array}$ \\
\hline $1-1^{\prime}$ & 5.5 & 95 & 4.75 & 9.7 & 140 & 1358 \\
$2-2^{\prime}$ & 9.6 & 72 & 2.7 & 11.0 & 52 & 572 \\
\hline
\end{tabular}

(Prochaska et al., 2008). These equations were recommended in The Specification of Geological investigation of Debris Flow Stabilization (DZ/T0220-2006), published by the China Ministry of Lands and Resources. For the Sanyanyu and Luojiayu torrent, two typical mud trace cross sections indicated in Fig. 3 in the lower channel reach, closely above the depositional zone, were surveyed and the estimated calculation results are shown in Table 4. The estimated peak velocity and peak discharge for the Sanyanyu basin are $9.7 \mathrm{~m} \mathrm{~s}^{-1}$ and $1358 \mathrm{~m}^{3} \mathrm{~s}^{-1}$, while for the Luojiayu basin, these figures are $11.0 \mathrm{~m} \mathrm{~s}^{-1}$ and $572 \mathrm{~m}^{3} \mathrm{~s}^{-1}$ (Table 4). This result is generally consistent with the estimation by $\mathrm{Hu}$ et al. (2010), who calculated the peak discharge of $1485 \mathrm{~m}^{3} \mathrm{~s}^{-1}$ for the Sanyanyu basin using the channel crosssection method. The peak discharge of the Sanyanyu debris flow event appears to be much higher when compared to many other events in this region (LIGC and TSIG, 1982). The failure of a check dam as well as of some natural rockfill dams in the Sanyanyu torrent must have contributed to a considerable increase of the peak flow discharge.

\section{$7 \quad$ Discussion and conclusions}

Debris flows are an important type of geological hazard in China, frequently affecting cities, towns, and villages located at mountain foothills or on alluvial fans. On 7 August 2010, two giant debris flows occurred in Zhouqu County, northwestern China. The debris flows were generated by a rainfall intensity of $77.3 \mathrm{~mm} \mathrm{~h}^{-1}$, while the antecedent rainfall was only $6.5 \mathrm{~mm}$ and thus, did not contribute to the debris flow triggering. Field investigations show that the debris supply was mainly derived from channel bed sediment and colluvium on the slopes alongside the channels. The debris flows were initiated by water runoff from loose colluvial materials and weathered bedrock that entrained sediment from rills and channels. The collapse of rockfill dams and check dams in the Sanyanyu catchment resulted in a considerable 
increase of the debris-flow volumes, which, in turn, resulted in longer travel distances over the existing fans. The volumes of the debris-flow deposits were estimated to be at least about 2.2 million $\mathrm{m}^{3}$. By using empirical equations that statistically relate flow velocity to the channel slope and the depth of flow, the peak velocity and the peak discharge of the debris flows were estimated to be $9.7 \mathrm{~m} \mathrm{~s}^{-1}$ and $1358 \mathrm{~m}^{3} \mathrm{~s}^{-1}$ for the Sanyanyu torrent and $11 \mathrm{~m} \mathrm{~s}^{-1}$ and $572 \mathrm{~m}^{3} \mathrm{~s}^{-1}$ for the Luojiayu torrent.

Prior to this catastrophic event, debris flow hazard had been recognized in the region, but its potential for such devastating impacts was not fully appreciated. The occurrence of disastrous debris flows triggered by the intense rainfall of 7 August 2010 indicates that under such circumstances the study areas are prone to catastrophic debris flows. As a consequence, it is necessary to improve the debris flow risk management. It is recommended to regulate and restrict the use of the hazardous areas susceptible to such debris flows, and to relocate the people currently living in such areas to safer places. It is therefore necessary to make hazard maps for the alluvial fans based on some return periods for different sedigraph inputs, which can be used by the planners of the Department of Land and Resources of Gansu Province and other agencies to design emergency and early warning plans and develop new land use policies.

The 7 August event clearly shows the effect of a built up area on the distribution of debris deposits on the fan (Figs. 11 and 12). The propagation and deposition of the debris flow material is not only determined by the topography of the fan but also by the location and characteristics of the buildings and the resistance against destruction of these buildings. Most hazard maps based on run-out modeling on alluvial fans take topography as the only controlling factor for the distribution of deposited material. However, more reliable results are obtained when the built up area is taken into consideration to assess the spatial distribution of the debris. The prediction of the degree of destruction of buildings during the run out and the subsequent changes in the flow pattern will, however, remain a very difficult task. Monitoring and early warning systems should be installed in the catchments above the potentially high risk areas. Construction of protective structures is still necessary to prevent repetition of the disasters because avoidance of debris flow hazard is not possible in Zhouqu city. These mitigation works are a significant effort to reduce the risk in areas recently affected by the catastrophic debris flow events.

Acknowledgements. This work was supported by the 973 program (No. 2011CB409903) and Key Projects in the National Science \& Technology Pillar Program (No. 2011BAK12B01). We express our gratitude to Yu Bin and Ma Dongtao for their comments on earlier versions of the manuscript. Yu Bin, Su Yongzhao, and Huang Wenjie helped with the field work.

Edited by: F. Luino

Reviewed by: two anonymous referees

\section{References}

Costa, J. E.: Physical geomorphology of debris flows, in: Developments and Applications of Geomorphology, edited by: Costa, J. E. and Fleischer, P. J., New York, Springer-Verlag, 269-317, 1984.

Hu, K. H., Ge, Y. G., Cui, P., Guo, X. J., and Yang, W.: Preliminary Analysis of extra-large scale debris flow disaster in Zhouqu County of Gansu Province, J. Mountain Sci., 28, 628-634, 2010 (in Chinese).

Hungr, O., Morgan, G. C., and Kellerhals, R.: Quantitative analysis of debris torrent hazards for design of remedial measures, Can. Geotech. J., 21, 663-677, 1984.

Hürlimann, M., Copons, R., and Altimir, J.: Detailed debris flow hazard assessment in Andorra, A multidisciplinary approach, Geomorphology, 78, 359-372, 2006.

Jakob, M. and Hungr, O.: Introduction, in: Debris-flow Hazards and Related Phenomena, edited by: Jakob, M. and Hungr, O., Springer, Berlin, 1-8, 2005.

Johnson, A. M. and Rodine, J. R.: Debris flow, in: Slope Instability, edited by: Brunsden, D. and Prior, D. B., Wiley, Chichester, 257361, 1984.

Lanzhou Institute of Glaciology and Cryopedology (LIGC) and Traffic Science Institute of Gansu Province, China (TSIG): Debris flow in Gansu Province, Publishing House of People's Transportation, Beijing, 156-190, 1982.

Ma, D. and Qi, L.: Study on comprehensive controlling of debris flow hazards in Sanyanyu Gully, Bulletin of Soil and Water Conservation, 17, 26-31, 1997 (in Chinese).

Pierson, T. C.: Erosion and deposition by debris flows at Mt. Thomas, North Canterbury, New Zealand, Earth. Surf. Proc., 5, 227-247, 1980.

Prochaska, A. B., Santi, P. M., Higgins, J. D., and Cannon, S. H.: A study of methods to estimate debris flow velocity, Landslides, 5, 431-444, 2008.

Qu, X., Zhang, T., Liu, X., Zhou, Q., and Zhang, X.: Analysis on the meteorological causes for the 8 August 2010 massive mudslide in Zhouqu, Gansu Province, Meteorological Monthly, 36, 102105, 2010 (in Chinese).

Rickenmann, D.: Empirical relationships for debris flows, Nat. Hazards, 19, 47-77, 1999.

Suwa, H. and Okuda, S.: Deposition of debris flows on a fan surface, Mt. Yakedake, Japan: Zeits, Geomorphologie, Suppl. Band, 46, 79101, 1983.

Takahashi, T.: Estimation of potential debris flows and their hazardous zones, J. Nat. Disaster Sci., 3, 57-89, 1981.

Tang, C., Zhu, J., and Li, W. L.: Rainfall triggered debris flows after Wenchuan earthquake, Bull. Eng. Geol. Environ., 68, 187-194, 2009.

Varnes, D. J.: Slope movement types and processes, in: Landslides Analysis and Control, edited by: Schuster, R. L. and Krizek, R. J., Transportation Research Board Special Report, National Research Council, Washington, DC, 176, 11-33, 1978.

Yu, B., Yang, Y. H., Su, Y. C., Huang, W. J., and Wang, G. F.: Research on the Giant Debris Flow Hazards in Zhouqu County, Gansu Province on August 7, 2010, J. Eng. Geol., 8, 437-444, 2010 (in Chinese).

Zhao, Y. C. and Cui, C. G.: A Study of rainstorm process triggering Zhouqu extremely mudslide on 8 August 2010, Torrential Rain and Disasters, 9, 289-295, 2010 (in Chinese). 